\title{
Analisa Rasio Keuangan dalam menilai Tingkat Efisiensi dan Efektivitas Operasi Pada Politeknik LP3I Kampus Bekasi Periode 2017/2018
}

\author{
Zaenah \\ STIE Dharma Agung \\ zaenah@gmail.com
}

\begin{abstract}
ABSTRAK
Tujuan penelitian ini membahasasbagaimana analisa laporan keuangan dalam menilai tingkat efisiensi dan efektifitas operasi pada Politeknik LP3I Kampus Bekasi periode 2017/2018 yang bertujuan untuk mengetahui kinerja keuangan apakah baik atau tidak dibanding dengan perusahaan sejenis. Data diperoleh dari laporan keuangan tahunan dan wawancara langsung kepada pihak terkait. Metode penelitian yang digunakan dalam peneltian adalah penelitian deskriptif dan menggunakan variable independen (bebas) yaitu tingkat efisiensi dan efektifitas yang diukur dengan beberapa sub variable diantaranya rasio likuiditas, rasio solvabilitas, rasio rentabilitas dan rasio aktifitas; Hasil analisa likuiditas, rasio yang dipergunakan mencakup rasio lancer (current Ratio), Rasio cepat (Quick Ratio), dan rasio kas (Csh Ratio). Analisa dengan rasio ini menunjukan Politeknik LP3I Kampus Bekasi tergolong likuid dalam memenuhi kewajiban-kewajiban jangka pendeknya pada saat jatuh tempo; Hasil analisa solvabilitas, rasio yang dipergunakan adalah rasio Hutang terhadap modal sendiri, dan rasio Hutang terhadap Aktiva. Analisis ini menunjukan bahwa kondisi keuangan Politeknik LP3I Kampus Bekasi Solvabel dalam menjamin seluruh kewajiban-kewajiban jangka pendek dan jangka panjang dengan modal dan aktiva yang ada; Hasil analisa rentabilitas, rasio yang dipergunakan adalah laba usaha berbanding dengan modal yang ada. Dari analisa ini didapat bahwa Politeknik LP3I Kampus Bekasi belum optimal dalam mengelola modalnya untuk bisa menghasilkan keuntungan yang lebih besar. Hasil analisa aktivitas, rasio yang dipergunakan adalah perputaran aktiva dalam menghasilkan omset. Dari analisa ini diperoleh bahwa perputaran aktiva belum cukup baik sehingga omset yang meningkat bukan diakibatkan karena perputaran aktiva melainkan dari factor lain.
\end{abstract}

Kata Kunci: Rasio Keuangan, Efisiensi, Efektifikas Operasi

\section{PENDAHULUAN}

Sebagaimana halnya seorang ahli psikolog mampu mengetahui tingkat kejiwaan seorang pasiennya, demikian pula seorang pengelola atau pemimipin keuangan dan pihak-pihak lainnya yang membutuhkannya harus mampu mengetahui sejauh mana kondisi keuangan perusahaannya (Abdurahmat, 2003). Perusahaan sebagai suatu organisasi bisnis yang bertujuan untuk memperoleh laba, tentu saja sangat perlu mendalami berbagai masalah keuangan yang ada dalam perusahaannya dan mengelolanya dengan baik. Analisa laporan keuangan dimaksudkan untuk memperhatikan hasil-hasil berupa angka yang dijadikan sebagai alat dalam suatu permainan yang kompetitif terhadap tujuan yang dicapai oleh manajer keuangan perusahaan (Munawir, 1995; P. Siagian, 2001).

Salah satu media komunikasi antara manajemen perusahaan dengan investor dan krediturnya serta pihak-pihak lain diluar perusahaan adalah laporan keuangan (Myer, 1994; Syafari, 2005). Demikian pentingnya laporan keuangan serta gambaran posisi keuangan yang ada didalamnya, maka setiap manajer di perusahaan harus mengerti karakteristik keputusan yang mampu memuaskan investor, kreditor serta pemangku kepentingan lainnya (Jarwanto, 1995; Munawir, 1995).

Laporan keuangan perusahaan adalah suatu informasi yang dianggap relevan oleh para investor. Karena hal tersebut bisa memberikan pertimbangan-pertimbangan yang efektif terhadap pengambilan keputusan untuk berinvestasi dan dapat menjamin kenyamanan dana yang diinvestasikan serta dapat memberikan keuntungan yang diharapkan oleh investor (Koontz, Harold, 1990; Riyanto, 1993). Selain itu, informasi yang terkandung dalam 
laporan keuangan banyak memberikan manfaat bagi pengguna apabila laporan tersebut dianalisis lebih lanjut sebelum dimanfaatkan sebagai alat bantu pembuatan keputusan. Dari laporan keuangan perusahaan dapat diperoleh informasi lain yang berkaitan dengan laporan keuangan (Langdon, 2005; Terry, 2006). Satu hal yang sangat penting untuk digarisbawahi adalah bahwa informasi yang diungkapkan dalam laporan keuangan dapat menunjukan seberapa besar nilai perusahaan (firm value).

Secara umum bentuk laporan keuangan dalam suatu perusahaan terdiri dari: Laporan rugi laba, laporan perubahan modal, neraca, laporan laba ditahan, dan laporan arus kas, Bentuk - bentuk laporan keuangan tersebut secara keseluruhan bukan suatu ketetapan yang mutlak untuk dilaporkan, namun perlu dipahami bahwa jenis analisa kinerja keuangan sangat bervariasi berdasarkan tujuan pihak pihak yang melakukan dan membutuhkan hasil analisa tersebut.

Dalam hal ini untuk menganalisa kinerja laporan keuangan, penulis terlebih dahulu mengidentifikasi pembahasan masalah dengan mengangkat judul dari pokok permasalahan pada kinerja keuangan yaitu "Analisa Rasio Keuangan dalam Menilai Tingkat Efisiensi dan Efektifitas Operasi Pada Politeknik LP3I Kampus Bekasi periode 2017/2018”.

\section{METODE PENELITIAN}

Obyek yang dilakukan dalam penelitian ini yaitu analisa akan dilaksanakan dengan menggunakan data laporan keuangan Politeknik LP3I Kampus Bekasi selama periode 2017/2018. Metode pengumpulan data yaitu metode riset lapangan dan metode riset kepustakaan. Sedangkan analisis yang digunakan yaitu rasio likuiditas yaitu yang mengukur kemampuan perusahaan untuk memenuhi hutang-hutang jangka pendeknya yang telah jatuh tempo; rasio Solvabilitas, untuk mengukur kemampuan perusahaan dalam membayar kewajibankewajibannya baik berupa hutang jangka pendek maupun jangka panjang seandainya perusahaan tersebut dilikuidasi/dibubarkan; rasio rentabilitas, untuk mengukur kemampuan perusahaan dalam menghasilkan keuntungan dibandingkan denga modal yang digunakan dan dinyatakan dalam prosentase; rasio aktifitas, menggambarkan aktivitas perusahaan dalam menggunakan aktiva yang dimiliki untuk menjalankan operasi terhadap kegiatan usaha yang dijalankan atau untuk mengukur efektifitas perusahaan dalam mengerjakan sumber dananya.

\section{HASIL PENELITIAN}

Pendekatan analisis keungan merupakan suatu kebutuhan perusahaan, dimana kebutuhan akan laporan keuangan ini dapat memberi gambaran atau laporan keuangan secara periodik yang dilakukan oleh perusahaan yang bersangkutan. Untuk mengadakan analisa berbagai komponen dari suatu laporan keuangan merupakan dasar untuk dapat menginterprestasikan kondisi dan hasil operasi perusahaan. Tindak lanjut untuk mengadakan pembahasan laporan keuangan pada Politeknik LP3I Kampus Bekasi "Analisa Laporan Keuangan" merupakan masalah utama dalam pembahasan. Untuk mencapai tujuan tersebut diperlukan data yang menyangkut data laporan keuangan, adapun data yang dimaksud adalah berupa neraca dan rugi laba (dapat dilihat pada lampiran), di mana dari tabel tersebut dapat dilihat dan diketahui perkembangan operasional Politeknik LP3I Kampus Bekasi dari tahun 2017 sampai dengan tahun 2018 sebagai berikut :

\section{Neraca}

Untuk lebih jelasnya mengenai perubahan Pos-pos Aktiva, Hutang dan Modal akan tampak pada tabel 1, tabel 2 dan tabel 3 .

Tabel 1 Perubahan Aktiva lancar Tahun 2017/2018

\begin{tabular}{cccc}
\hline Tahun & Jumlah & Perubahan & Prosentase \\
\hline 2016 & Rp. 1.082.778.499,- & - & - \\
\hline 2017 & Rp. 1.556.035.843,- & Rp. 473.257.344,- & Naik 144\% \\
\hline 2018 & Rp. 3.077.053.309,- & Rp. 1.521.017.466,- & Naik $197 \%$ \\
\hline
\end{tabular}

Tabel 2 Perubahan Hutang Lancar Tahun 2017/2018

\begin{tabular}{cccc}
\hline Tahun & Jumlah & Perubahan & Prosentase \\
\hline 2016 & Rp. 178.354.772,- & - & - \\
\hline 2017 & Rp. 304.518.960,- & Rp. 126.164.188,- & naik $170 \%$ \\
\hline 2018 & Rp. 260.209.333,- & (Rp 44.309.627,-) & naik 115\% \\
\hline
\end{tabular}


Tabel 3 Perubahan Modal Tahun 2017/2018

\begin{tabular}{cccc}
\hline Tahun & Jumlah & Perubahan & Prosentase \\
\hline 2016 & Rp. 2.877.607.941,- & - & - \\
\hline 2017 & Rp. 3.651.736.363,- & Rp 774.128.422,- & naik $127 \%$ \\
\hline 2018 & Rp. 4.652.841.937,- & Rp . 1.001.105.574,- & naik 127\% \\
\hline
\end{tabular}

\section{Laporan Rugi-Laba}

Untuk lebih jelasnya mengenai perubahan Pos-pos Pendapatan dan Biaya akan tampak pada tabel 4 dan tabel 5 .

Tabel 4 Perubahan Pendapatan Tahun 2017/2018

\begin{tabular}{cccc}
\hline Tahun & Jumlah & Perubahan & Prosentase \\
\hline 2009 & Rp 3.731.484.919,- & - & - \\
\hline 2010 & Rp 5.242.566.694,- & Rp 1.511.081.775,- & naik 140 \% \\
\hline 2011 & Rp 5.816.836.500,- & Rp 574.269.806,- & Naik 111 \% \\
\hline
\end{tabular}

Tabel 5 Perubahan Biaya Tahun 2017/2018

\begin{tabular}{cccc}
\hline Tahun & Jumlah & Perubahan & Prosentase \\
\hline 2009 & Rp 3.064.978.382,- & - & - \\
\hline 2010 & Rp 4.468.438.272,- & Rp 1.403.459.890,- & Naik 145\% \\
\hline 2011 & Rp 4.815.730.926,- & Rp 347.292.654,- & Naik 107\% \\
\hline
\end{tabular}

Pada analisis rasio keuangan ditemukan pada setiap perusahaan dapat dipergunakan sebagai dasar pembuatan ramalan akan perkembangan perusahaan di masa datang dan akan menentukan posisi perusahaan dibandingkan dengan perusahaan lain. Dalam melakukan analisa rasio, peneliti menggunakan beberapa jenis rasio yang dianggap cukup relevan. Disebabkan karena sulitnya mendapatkan data dari perusahaan lain yang sejenis, maka peneliti menggunakan historical standard yaitu penentuan standar berdasarkan catatan-catatan perusahaan di masa lalu, untuk menilai posisi keuangan atau kemajuan hasil operasi perusahaan.

Laporan keuangan selengkapnya untuk tahun 2017 sampai dengan tahun 2018 dapat dilihat pada lampiran.

\section{Rasio Likuiditas}

Umumnya para pemakai laporan maupun para penganalisa, hal pertama yang menarik mereka adalah masalah likuiditas. Karena dari sini akan dapat diketahui apakah perusahaan mampu untuk memenuhi kewajiban-kewajiban jangka pendeknya. Dan untuk mengetahui rasio likuiditas ini biasanya digunakan peninjauan perhitungan sebagai berikut :
Tabel 6 Current Ratio

\begin{tabular}{c|c|c|c}
\hline Tahun & Aktiva Lancar & Hutang Lancar & $\%$ \\
\hline 2016 & Rp. 1.082.778.499,- & Rp. 178.354.772,- & 607 \\
\hline 2017 & Rp. 1.556.035.843,- & Rp. 304.518.960,- & 511 \\
\hline 2018 & Rp. 3.077.053.309,- & Rp. 260.209.333,- & 1.182 \\
\hline
\end{tabular}

Pada tahun 2017 jumlah aktiva lancar sebesar $\mathrm{Rp}$ 1.082.778.499,- dan hutang lancarnya sebesar Rp 178.354.772,- sehingga current rasio adalah sebesar $607 \%$ atau 6,07:1 artinya setiap Rp 1,- hutang lancar dijamin Rp 6,07 harta lancar. Pada tahun 2017 ini, perusahaan termasuk likuid.

Tahun 2017 jumlah aktiva lancar Rp 1.556.035.843,- dan hutang lancar sebesar $\mathrm{Rp}$ 304.518.960,- sehingga current rationya adalah $511 \%$ atau 5,11:1 artinya setiap Rp 1,- hutang lancar dijaminkan $\mathrm{Rp}$ 5,11 aktiva lancar. Nilai ini lebih rendah dari tahun sebelumnya, dan pada tahun 2018 Polieknik LP3I kampus Bekasi termasuk ke dalam perusahaan yang likuid.

Dan perkembangan current ratio sebesar $1.182 \%$ atau 11,82:1 terjadi pada tahun 2018 yang berarti bahwa setiap $\mathrm{Rp} 1$,- hutang lancar dijaminkan dengan $\mathrm{Rp}$ 11,82 aktiva lancar. Angka ini diperoleh dari perbandingan aktiva lancar sebesar Rp 3.077.053.309,- dan kewajiban lancar Rp. 260.209.333,- Sebenarnya tidak ada ketentuan tentang berapa tingkat current ratio yang dianggap baik atau yang harus dipertahankan oleh suatu perusahaan. Karena biasanya tingkat current ratio itu sangat tergantung pada jenis usaha masing-masing perusahaan. Akan tetapi sebagai pedoman umum tingkat ratio 2,00 untuk Rp 1,- hutang lancar sudah dianggap baik. Sehingga pada tahun 2018, Politeknik LP3I Kampus Bekasi ini pun termasuk ke dalam kategori perusahaan yang sangat likuid.

\section{Cash Ratio (Rasio Kas)}

Rasio ini dapat ditentukan dengan jalan membandingkan pos kas ditambah dengan efek dan kemudian dibandingkan dengan hutang lancar yang terdapat pada Neraca Politeknik LP3I Kampus Bekasi.

Tabel 7 Cash Ratio

\begin{tabular}{cccc}
\hline Tahun & Kas + Efek & Hutang Lancar & $\%$ \\
\hline 2016 & Rp. 607.770.479,- & Rp. 178.354.772,- & 340 \\
\hline 2017 & Rp. 612.733.509,- & Rp. 304.518.960,- & 201 \\
\hline
\end{tabular}


2018 Rp. 2.054.745.783,- Rp. 260.209.333,- 7896

Dari hasil perhitungan Analisa cash ratio yaitu dari tahun 2017 ke 2018 mengalami penurunan sebesar $139 \%$ dikarenakan adanya kenaikan hutang lancar sebesar $170 \%$ dari tahun sebelumnya sedangkan nilai kas dan efeknya meningkat hanya $101 \%$. Pada tahun 2018 rasio ini meningkat tajam yaitu sebesar $7896 \%$, hal ini terjadi karena pada tahun ini jumlah hutang lancar menurun dan nilai kas dan efek meningkat cukup tinggi.

Cash ratio perusahaan sebesar $7896 \%$ pada tahun 2018 menunjukkan bahwa perusahaan mampu melunasi kewajiban jangka pendeknya dengan dana dalam bentuk kas sebesar $\mathrm{Rp}$ 78,96. Sedangkan dana pada tahun 2017 hanya sebesar Rp 2,01. Dan pada tahun 2009 dana yang ada sebesar $R p$ 3,40, kesemua dana tersebut dipergunakan untuk menjamin setiap $\mathrm{Rp}$ 1,hutang lancar. Sehingga cash ratio dari tahun 2017-2018 pada Politeknik LP3I Kampus Bekasi termasuk ke dalam kategori perusahaan yang likuid.

\section{Quick Ratio}

Rasio ini dapat diketahui dengan cara membandingkan antara kas ditambah efek ditambah dengan piutang kemudian dibandingkan dengan hutang lancar yang terdapat pada neraca perusahaan.

Tabel 8 Quick Ratio

\begin{tabular}{cccc}
\hline Tahun & Kas + Efek + Piutang & Hutang Lancar & $\%$ \\
\hline 2016 & Rp. 701,992,974 & Rp. 178.354.772,- & 394 \\
\hline 2017 & Rp. 1,032,045,851 & Rp. 304.518.960, & 339 \\
\hline 2018 & Rp. 2,424,745,159 & Rp. 260.209.333,- 932 \\
\hline
\end{tabular}

Pada tahun 2009 jumlah quick asset adalah Rp 701.992.974,- dan kewajiban lancarnya adalah Rp 178.354.772,- sehingga quick ratio yang terjadi sebesar 394\% atau 3,94:1 sehingga $\mathrm{Rp}$ 3,94 digunakan untuk menjamin $\mathrm{Rp}$ 1,- untuk hutang lancar. Untuk tahun 2010 cenderung menurun dengan perbandingan 3,39:1 sehingga $\mathrm{Rp} \quad 3,49$ digunakan untuk menjamin $\mathrm{Rp}$ 1,- hutang lancar. Sedangkan untuk tahun 2017 meningkat cukup tinggi menjadi 9,32:1 yaitu setiap $\mathrm{Rp}$ 9,32 digunakan untuk menjamin $\mathrm{Rp}$ 1,- hutang lancar.

Semakin besar hasil perhitungan rasio ini menunjukkan likuiditas yang semakin baik, sebaliknya semakin kecil hasilnya menunjukkan tingkat likuiditas yang semakin buruk. Jika dilihat dari hasil perhitungan diatas maka Politeknik LP3I Kampus Bekasi ini dapat memenuhi kewajiban-kewajiban jangka pendeknya dengan menggunakan quick asset.

Dengan melihat perkembangan selama 2 (tiga) tahun terakhir sejak tahun 2017 sampai dengan tahun 2018 baik current ratio, cash ratio maupun quick ratio sangat mengalami perubahan yang sangat berarti. Untuk dapat memperjelas keadaan likuiditas Politeknik LP3I Kampus Bekasi, maka di bawah ini akan diperlihatkan daftar tabel rasio yang telah dianalisa oleh peneliti dapat dilihat pada tabel 9 .

Tabel 9 Rasio Likuiditas

\begin{tabular}{cccc}
\hline Tahun & Current Ratio & Cash Ratio & Quick Ratio \\
\hline 2016 & 6,07 & 3,40 & 3,94 \\
\hline 2017 & 5,11 & 2,01 & 3,39 \\
\hline 2018 & 11,82 & 78,96 & 9,32 \\
\hline
\end{tabular}

\section{Rasio Solvabilitas}

Rasio solvabilitas akan memperlihatkan apakah modal yang diperoleh telah diinvestasikan dalam pos-pos dengan keseimbangan yang baik serta apakah ada keseimbangan antara modal yang berasal dari pinjaman dan modal yang berasal dari pemilik dan apakah posisi keuangan jangka panjang menunjukkan gejala membaik, hal ini dapat dilihat pada perhitungan solvabilitas dengan cara di bawah ini.

Rasio yang menunjukkan seberapa besar hutang-hutang perusahaan dapat dilunasi dengan modal sendiri. Rasio ini makin tinggi berarti bahwa semakin besar dana yang diambil dari luar perusahaan. Rasio yang tinggi relatif kurang baik ditinjau dari sudut solvabilitas karena bila terjadi likuiditas, perusahaan akan mengalami kesukaran. Untuk perhitungan Total Debt To Total Equity Ratio dari tahun 2009 sampai dengan tahun 2011, dapat dilihat pada tabel 10 .

Tabel 10 Total Debt To Total Equity

\begin{tabular}{cccc}
\hline Tahun & Total Hutang & Modal Sendiri & $\%$ \\
\hline 2016 & Rp. $286,372,844$ & Rp. 2,877,607,941 & 10 \\
\hline 2017 & Rp. $316,567,747$ & Rp. 3,651,736,363 & 9 \\
\hline 2018 & Rp. $240,858,920$ & Rp. 4,652,841,937 & 5 \\
\hline
\end{tabular}


Dari perhitungan rasio tersebut di bawah ini selama periode tahun 2017 sampai dengan tahun 2018, tingkat total debt to total equity untuk tahun 2017 sebesar 9\% mengalami penurunan sebesar $1 \%$ bila dibandingkan dengan tahun 2017 yaitu sebesar 10\%. Total debt to total equity pada tahun 2018 juga mengalami penurunan sebesar $4 \%$ bila dibandingkan dengan tingkat rasio pada tahun 2017 yaitu sebesar 9\%. Penurunan total debt to total equity yang terjadi setiap tahun disebabkan terjadinya kenaikan modal sendiri yang cukup besar dibandingkan dengan kenaikan hutangnya. Hal ini dapat mencerminkan bahwa pada tahun 2017 sampai dengan tahun 2018 perusahaan yang solvabel.

Rasio yang menunjukkan seberapa besar hutang-hutang perusahaan dilunasi oleh aktiva. Dan rasio ini digunakan untuk mengetahui berapa besar bagian dari setiap rupiah aktiva yang digunakan untuk menjamin keseluruhan hutang perusahaan;

Tabel 11 Total debt To Total Assets Ratio

\begin{tabular}{cccc}
\hline Tahun & Hutang & Total Aktiva & $\%$ \\
\hline 2016 & $286,372,844$ & $3,163,980,780$ & 9 \\
\hline 2017 & $316,567,747$ & $4,366,154,110$ & 7 \\
\hline 2018 & $240,858,920$ & $5,716,425,856$ & 4 \\
\hline
\end{tabular}

Di dalam perhitungan tingkat rasio tersebut selama periode 3 (tiga) tahun yaitu dari tahun 2017sampai dengan tahun 2018 menunjukkan bagian dari setiap rupiah aktiva yang digunakan menjamin keseluruhan hutang perusahaan. Pada tahun 2017 total debt to total assets sebesar 9\% yang berarti bahwa $\mathrm{Rp}$ 0,09 dari setiap aktiva dijadikan jaminan hutang. Pada tahun 2017 total debt to total assets sebesar 7\% yang berarti bahwa $\mathrm{Rp}$ 0,07 dari setiap rupiah aktiva dijadikan jaminan hutang perusahaan. Pada tahun 2018 total debt to total assets sebesar 4\% yang berarti bahwa $\mathrm{Rp}$ 0,04 dari setiap rupiah aktiva dijadikan jaminan hutang perusahaan.

Hasil dari perhitungan Total Debt To Total Assets Ratio dari tahun 2017 sampai dengan tahun 2018 mencerminkan bahwa Politeknik LP3I Kampus Bekasi ini termasuk perusahaan yang solvabel.

Dengan melihat perhitungan selama 3 (tiga) tahun terakhir sejak tahun 2017 sampai dengan tahun 2018 baik dari total debt to total equity dan total debt to total assets mengalami perubahan, untuk dapat memperjelas keadaan solvabilitas Politeknik LP3I Kampus Bekasi yang telah diperhitungkan dengan 2 (dua) macam rasio dapat dilihat pada tabel 12 .

Tabel 12 Rasio Solvabilitas

\begin{tabular}{ccc}
\hline Tahun & Total Debt To Total Equity & Total Debt To Total Assets \\
\hline 2016 & $10 \%$ & $9 \%$ \\
\hline 2017 & $9 \%$ & $7 \%$ \\
\hline 2018 & $5 \%$ & $4 \%$ \\
\hline
\end{tabular}

\section{PEMBAHASAN}

Peneliti menggunakan analisa rasio sebagai alat pengendalinya. Karena dengan menggunakan analisa rasio tersebut juga dapat diketahui mengenai kekuatan dan kelemahan perusahaan. Dalam melakukan analisa rasio ini seperti sudah dijelaskan di muka, peneliti menggunakan historical standard yaitu penentuan standar berdasarkan catatan-catatan perusahaan di masa yang lalu, untuk menilai posisi keuangan atau kemajuan hasil operasi perusahaan.

Berikut ini adalah gambaran semua analisa rasio Politeknik LP3I Kampus Bekasi yang dibuat pada tahun 2016 sampai dengan tahun 2018. Laporan analisa rasio selengkapnya pada tahun 2017 sampai dengan tahun 2018 dapat dilihat pada table 4.19 , dimana laporan ini dibuat untuk mengetahui posisi keuangan perusahaan tersebut dan untuk mengetahui pengendalian keuangannya.

Dari lampiran tersebut atau berdasarkan perhitungan-perhitungan tersebut, yang mana semua perhitungan tersebut ditinjau berdasarkan likuiditas, solvabilitas, rentabilitas dan aktivitas dapat dilakukan pengamatan terhadap nilai rasio perusahaan tersebut. Perhitungan-perhitungan tersebut adalah sebagai berikut :

\section{Likuiditas}

Di lihat dari posisi likuiditas pada perusahaan ini, nampak adanya kenaikan current ratio, cash ratio dan quick ratio yang menandakan bahwa perusahaan dalam kondisi yang aman untuk jangka waktu yang pendek. Hal ini bisa dihubungkan dengan adanya perbandingan atau tingkat prosentase yang bertambah tinggi dari 
tahun dasarnya. Bagian pada pos aktiva lancar yang membaik dan memiliki pengaruh yang akan mendorong rasio likuiditas adalah perputaran piutang yang kian cepat kembalinya ke dalam aktiva lancar.

\section{Solvabilitas}

Melihat kemampuan perusahaan melalui peninjauan rasio solvabilitas ini, tampak adanya suatu harapan membaik tingkat solvabilitas dari tahun dasar dan ini didukung pula pada peninjauan perhitungan rasio berupa rasio modal sendiri dengan hutang atau aktiva tetap dengan hutang, jelas hal ini akan menimbulkan suatu kepercayaan dari berbagai pihak khususnya para kreditur.

\section{Rentabilitas}

Hasil peninjauan perhitungan tingkat rentabilitas meskiun terjadi penurunan sebesar 3 $\%$ dari tahun dasar, namun hal ini masih dianggap baik kondisinya karena masih diangka yag cukup aman dan ini sangat berpengaruh bagi kelanjutan perusahaan dan membuktikan pula terus meningkatnya efisiensi perusahaan walaupun terjadi penurunan pada tahun 2017 dan 2018.

Margin rasio merupakan tantangan untuk bertindak lebih efisien lagi, sedangkan bertambah besarnya operating margin rasio akan sangat merugikan sekali, ini di karenakan pendapatan bersih banyak diserap oleh biayabiaya operasi untuk operasi, sehingga dari rasio ini akan berpengaruh kepada berkurang efisiensi perusahaan.

\section{Aktifitas}

Dana yang tertanam di dalam keseluruhan aktiva dapat menghasilkan pendapatan bagi perusahaan. Perputaran asset selama tahun 2017 sampai dengan tahun 2018 mengalami penurunan, sehingga hal ini menjadi tugas manajemen untuk mencari kebijaksanaan agar perputaran asset pada tahun yang akan datang bisa menjadi lebih baik dan berdampak untuk menghasilkan pendapatan.

\section{KESIMPULAN}

Kondisi keuangan perusahaan selama tahun 2017 sampai dengan tahun 2018 mampu menghasilkan laba dari tahun ke tahun yang semakin membaik. Laba yang diperoleh pada tahun 2016 dapat ditingkatkan menjadi 161\% pada tahun 2017. Dan mengalami peningkatan kembali pada tahun 2018 yaitu sebesar 502\%. Hal ini disebabkan adanya pertumbuhan omset yang berasal dari program D3 (khusus tingkat III) yang semula dikelola kantor pusat mulai tahun 2010 dikelola langsungg oleh Politeknik LP3I kampus Bekasi. Dan juga program S1 yang baru dibuka sebagai program pendidikan lanjutan bagi mahasiswa D3 yang telah menyeleasikan studinya.

Peranan Analisa laporan keuangan sebagai alat pengendalian keuangan antara lain untuk kebijakan sumber dana jangka pendek dan jangka panjang, serta sebagai alat pengendali pengeluaran-pengeluaran atau biaya-biaya yang dibutuhkan dalam rangka kelangsungan hidup perusahaan.

Informasi mengenai analisa rasio sangat berguna dan berperan untuk menyajikan umpan balik kinerja secara periodik akan memicu perasaan subjektif mengenai keberhasilan dan kegagalan bagi para manajer yang bertanggungjawab dalam mengkonsumsi sumber daya untuk mencapai sasaran perusahaan yang dituju yaitu selama tahun 2016-2018 posisi likuiditas masih menunjukkan kemampuan perusahaan untuk memenuhi kewajibankewajiban jangka pendek perusahaan. Meskipun di tahun 2017 terjadi kondisi penurunan dari segi likuiditas namun berangsur membaik pada tahun 2018, Sehingga perusahaan ini dapat dikategorikan ke dalam perusahaan yang likuid; Berdasarkan keadaan perusahaan dalam tinjauan rasio solvabilitas ini, maka kondisi keuangan perusahaan tergolong baik dan termasuk ke dalam perusahaan yang solvabel; Kemampuan perusahaan daalam menghasilkan laba belum cukup optimal hal ini terlihat rendahnya penggunaan sumber modal yang dikelola untuk menghasilkan keuntungan/laba dkarenakan factor kebijakan dari pemilik perusahaan. Sementara tingkat efisiensi meningkat di tahun 2018; Dari segi rasio aktifitas terutama dilihat dari turnover operating assets rasio, perputaran aset juga cukup baik meskipun di tahun 2018 terjadi penurunan, hal ini dikarenakan kurangnya optimalisasi penggunaan sumber pendapatan untuk menghasilkan aktiva. 


\section{DAFTAR PUSTAKA}

Abdurahmat, F. (2003). Organisasi dan Manajemen Sumber Daya manusia. Jakarta: Rineke Cipta.

Jarwanto. (1995). Pokok-pokok Analisa Keuangan. Yogyakarta: BPFE.

Koontz, Harold, C. O. D. (1990). Manajemen. Jakarta: Erlangga.

Langdon, K. (2005). Smart Finance. Jakarta: PT. Elex Media Komputindo.

Munawir. (1995). Analisa Laporan keuangan. Yogjakarta: Liberty.

Myer, J. N. (1994). Financial Statement Analysis. Jakarta: Rineke Cipta.

P. Siagian. (2001). Manajemen Sumber Daya Manusia. Jakarta: Bumi Aksara.

Riyanto, B. (1993). Dasar-dasar Pembelajaan Perusahaan. Yogjakarta: BPFE.

Syafari, S. (2005). laporan Keuangan. Jakarta: Bumi Aksara.

Terry, G. R. (2006). Prinsip-prinsip Manajemen. Jakarta: Bumi Aksara. 